\title{
PAPERS OF AN AFRICAN KING COLLECTED BY JACQUES HYMANS
}

\author{
Jan Vansina \\ UNIVERSITY OF WISCONSIN-MADISON
}

During a visit in the summer 1970, Jacques Hymans, professor of History at San Francisco State Unives sity, found discarded papers strewn over the floor of an abandoned European-style house at Mushenge (Nsheng), the capital of the Kuba kingdom, zone Mweka, West Kasai, Democratic Republic of Congo. He salvaged them and then kept them at home. After his death Ms Kelley Hymans gave the papers to the collections of Memorial Library of the University of Wisconsin-Madison. To this a notebook, which Wisconsin obtained through the good offices of Professor Mary Douglas, has been added. This contains a census of the capital for 1939-40 carried out by Jules Lene (Lyeen) as tribute collector for the Kuba king.

Since early colonial times the Kuba people were well-known in Europe for their sculpture and their artistic textiles, and because they formed a single kingdom headed by a "divine" king. This was also the only territory in the Belgian Congo where "indirect administration" was officially practiced after 1920 . Under such circumstances it is not surprising that the Kuba capital Nsheng, known as Mushenge, eventually became a minor tourist attraction for amateurs of their arts.' After independence, travel in Congo became difficult and the 'As far as 1 know, the earliest recorded visit of such a tourist is the mention of a certain van Essche, artist-painter on 1 January 1940, found in the Hymans papers. For tourism see Guide du voyageur au Congo Belge et au Ruanda-Urundi, published in Brussels by the colonial office for intending tourists. In the 1953 edition (p. 400) we are told that the Kuba are a people of artists and later on that one can buy interesting "objets de collection" at Mushenge but made for commercial sale: objects in ivory, in wood and in iron-and one of the five illustrations in color in that edition is a Kuba mask. This collection of papers makes relatively frequent references to masks and other art objects, and even includes a request by the official cooperative of carvers to the king in December 1954 to decree ininimum prices so as to avoid unfair dumping.

History in Africa 30 (2003), 455-460. 
prestige of Mushenge declined, but some of its fascination remained, and Hymans was one of the persons still attracted to it. His last visit to Mushenge occurred in 1970, not long after the death of king Bop Mabinc maKyeen. It is on that occasion that he salvaged the papers now in Madison.

The documents turn out to be the surviving remnants of the archive kept by Bop Mabiinc maKyeen. They cover the period from 1920 to 1969 , or nearly all his public career. In 1920 the Belgian minister of colonies decided that the Kuba kingdom was to be subject to indirect rule, the only territory in the Belgian Congo to achieve this status. This explains why the king's administration affected between 70,000 to 100,000 people and covered an area as large as New Jersey or, perhaps more to the point, to that of the colonial power Belgium itself, and why also his administration encompassed the full range of public affairs.

Bop Mabiinc maKyeen was the brother of Kwet Mabiinc maKyeen, who became king of the Kuba late in 1919. Kwet was paralyzed and his brother Bop was delegated in his stead to take charge of those public functions in the "Territory of the Bakuba" (after 1950 "Mweka Territory") which required traveling. Thus began his public career, and perhaps his habit of keeping records. In November 1939 Kwet died, and Bop succeeded as king in his own right. On 30 June 1960 the country became independent and lost its special status. Yet Bop managed to maintain and, indeed, extend his unique position as "great chief" until his death in 1969.

We know that in the 1950s these papers were kept in one or more footlockers and were in charge of a secretary. But we don't know how they were organized, or even if they were organized at all. In any case the some 710 items salvaged were but a hapliazard cross-section of what had been a much larger body of documents and they were in complete disarray. Hence the collection has been organized only in chronological order. This was feasible because most papers are dated and because various clues in their texts have made it possible to group most of the some124 undated papers by decade. Although a majority of the papers consists of incoming correspondence stemming from both Europeans and Africans, there is also some outgoing correspondence, especially from ca. 1959 onwards, as well as accounts (private and public accounts were obviously mixed, and some accounts refer to bridewealth) and notebooks with census materials, tax records, lists of tribute asked and/or paid.

Among a miscellany of other documents one encounters a few others relating to various aspects of colonial administration such as ag- 
ricultural matters, weapons permits, lists of corvée labor requested to work on roads or on the public buildings, the gathering of palm fruit, the compulsory growing of cash crops, and even one which carefully records the numbers of fowls and eggs given to passing European administrators and guests. More closely related to the management of the king's own affairs are one or two inventories of valuable objects kept by the king, related lists of goat flocks, lists of local titles of office, a list of the king's wives with the new clothes given to each of them, a handmade calendar, and the beginnings of someone's (not the king!) diary. A packet of owl or hawk's feathers was also found with these papers, which is normal, as these feathers were insignia of rank and could only be kept and distributed by the king or in the provinces by one of the main chiefs "those of the eagle-feathers."

The main drawback of the filing system by chronological ordering is that users of the collection might be tempted to use temporal succession to infer that a certain type of document or of correspondents only appears at date $X$ or $Y$ or to use other inferences by an argument from silence, despite the fact that the whole corpus consists of a haphazard remnant that is only a small portion of what once was a far more voluminous set of papers. In particular the preponderance in numbers of documents from 1959 to 1961 might also well be haphazard rather than systematic.

Most of the documents are easily legible, although some are damaged in places, but there also is a sinall number of fraginents or scraps of paper. Apart from dannaged places and lacunae, most texts are easy to read. The sizes of documents vary. Many are half-page size or even less, while a few are folio size. Most are written in ink, but some are in pencil, and there is some typing. The reverse of a good number of pages has been reused for later notes or even correspondence. Nearly all communications are only one page long or less, but a few long documents from 1959-62 relate to politics. Most items are written in more or less standard Tshiluba, the provincial lingua franca in Kasai province. In addition there are also a fair number of documents in French, a few in Kituba (Monokituba), the lingua franca in use between Kwango and Kwilu, and two each in Lingala and Bushong. ${ }^{2}$ The chronological distribution of the surviving papers is as follows: about 50 from 1920 to 1940 before Bop became king; about 290 for

${ }^{2}$ Some researchers miglt want to use the Tshiluba grammar and/or dictionary by E. Willems (but allow for variation in grammar and spelling, as most texts are in the Lulua variant of Tshiluba). The largest community of Tshiluba-speakers in the USA lives in Milwaukee. 
1940 to 1958; about 250 for 1959 to 1961 (the transition to independence); and about 70 for 1962 to 1969.

This distribution is in part accidental. The small number of documents from 1920 to 1940 is not surprising, in view of "natural" attrition under the conditions in which they were kept, but the comparatively large numbers for the years 1959 to 1961 covering the transition to independence might well be accidental, since one would have expected larger numbers of papers to have survived for the most recent years 1962 to 1969 . As the overall chronological distribution shows, the collection as a whole relates primarily to the colonial period, but contributes significantly to our understanding of the passage to independence.

In assessing the value of this corpus it is be useful to start with what it does not contain. There is no detailed record of the Kuba king's "grass roots" administration, although there are hints. The main reason for this is that in those days the Kuba were still first and foremost an oral society. Even the recurring and extensive political deliberations were not recorded, nor were administrative orders. What was written down were accounts, lists of all sorts from headcounts to records of tribute paid, and summonses or correspondence from and to Kuba-and others-who lived far from the capital. Moreover, the Kuba king was not allowed to keep any of the records generated by his "customary tribunals." These were kept at the seats of the various tribunals and nearly all of them have probably perished-and with them the richest written source about day-to-day social history.'

Insofar as the colonial period is concerned, the originality of this collection resides in the fact that it is, as far as I know, the only one consisting of papers documenting various concrete and "usual" activities of an African chief. In the Kuba case the European administration in Congo left vast numbers of official documents both in manuscript and in print, but they do not include any account of personal relations between agents of the administration and Bop either as heir-designate or as king. They do not mention his day-to-day activities nor do they give inuch concrete evidence about his relations with his subjects. Similarly, the other main archival holdings of the period

'For the 1950s a good deal of concrete evidence in this regard is preserved in Vansina, "Kuba Field Notes," 6 reels of microfilm, available from the Center for Research Libraries, MF-4975 
whether generated by missions, mainly the American Presbyterian Christian Mission (APCM) and the Catholic order of Scheut) or commercial companies, mainly the Compagnie du Kasai (CK) and the Chemin de fer du Bas-Congo au Katanga (BCK) focus only on their official activities.

In contrast the Hymans papers give us (i) a good idea of the extent of the network of relationships entertained by Bop and allow us to identify the main agents he used to rule, (ii) their requests for patronage, (iii) a glimpse of Bop's varied and extensive business and administrative activities, and (iv) some indication of his relations with Europeans, traders and missionaries as well as state agents. These papers add flesh to the dry bones of all the existing European records. They inform us to some extent of what was actually going on below the "official" surface and hence reach beyond the official interpretations that state agents, missionaries and commercial agents tended to impose on their superiors. Thus social anthropologists used to ask in the 1950s how African kings actually ruled in a colonial setting, and for the Kuba these papers provide a good deal of the answer. This also means, however, that the Hymans papers are at their most illuminating when placed in the framework known by the other records. ${ }^{4}$

The Hymans papers are also quite valuable for the period of the transition of to independence at the local level, since the years 1959 . 1962 are particularly well-documented in them, even though they still are far from a complete record. Still they allow us better to grasp not only the unexpected turn taken by events and the resulting confusion and turmoil of the period. They show in particular exactly how and how fast the whole colonial apparatus of coercive labor began to unravel, and in doing so disrupted economic life and led to a decline in the living standards of most of the population. Information about the period of transition at the local rural level during the first two or three years of independence is particularly welcome because so far-in contrast to the situation at the national level-not much was known about this.

In addition local politics during these years in the territory are fascinating, for they show how Bop managed to preserve a kingdom that was no longer legally recognized, and how he managed to establish

"The main account of the kingdom or "chefferie des Bakuba" for this period is Jan Vansina, "Les Kuba et l'administration territoriale de 1919 à 1960," Cultures et Développement 4(1972), 27S-325; See also idem., "Du royaume kuba au "tcrritoire des Bakuba," Etudes Congolnises 2(1969), 3-53, and idem., "Les mouvements religieux kuba (Kasai) à l'époque coloniale," Etudes d'Histoire Africaine 2(1971), 155-87. 
himself in a more powerful position than had ever been the case in colonial times. Indeed, by 1965 he had wrested political control over his territory from the provincial, and even the national, authorities. In this he succeeded through his effective role as the advisor and protector of his people, whom he kept out of the major civil war in Kasai, through the use of propaganda in his role of "divine king," and through efficient patronage that provided him both with the intelligence about national regional and local events he required, and with agents who could and did intervene in provincial political affairs.

Finally the Hymans papers are also quite valuable for linguistic purposes, particularly for the study of onomastics, since they contain a very large selection of Kuba names and in general of nicknames. In addition they are valuable for the study of the gradual penetration of Tshiluba and its written standardization as a lingua franca in the region where apart from the missionaries, it still constituted a rudimentary trade jargon by 1920 . Soon, however, it acquired common epistolary conventions and a less elementary grammar, albeit one based on the Lulua dialect, also influenced by Tshikete, rather than on the official Luba, while it continued to contain unusual lexical borrowings mostly from Bushong."

'These materials are available digitally at http://www.library.wisc.edu/reslist.etexta.html and include this introduction and a rough list of contents. 